\title{
THE JURISDICTIONAL BASIS OF THE INTERNATIONAL CRIMINAL COURT
}

\author{
Sarah Viau', Queen's University
}

"And so today the peoples of the world ask for philosophical vision in meeting the practical question: What rights, if any, can a man claim of me not because he is my brother or my neighbor or my colleague or co-religionist or fellow-citizen, but just because he's human? ${ }^{\prime 2}$

It is generally accepted that human rights abuses, like genocide, war crimes, and crimes against humanity, have a long history. ${ }^{3}$ Human rights advocate Richard Falk asks,

is this indulgence of genocidal politics simply inherent to world order, or can it be overcome by a series of reforms such as establishing an enforcement capability under the control of a financially independent UN or regio nal auspices, thereby weakening the ties to geopolitical calculations; [and] creating an international criminal court with competence to address genocide? ${ }^{4}$

As Falk notes, the International Criminal Court represents an idealistic mentality, optimistic about the possibility of reforming the international system in order to prevent certain behaviour by establishing an international authority capable of punishment and deterrence. Growing support for the International Criminal Court can be directly related to the growth of legal regimes committed to the protection of human rights, and to the growth of international humanitarian law, which presupposes a conception of the individual as the bearer of rights and obligations, as well as an interest in protecting the individual from gross violations of human rights. Now that the International Criminal Court has received sufficient ratifications from Member States of the United Nations, it exists as a legal entity with jurisdiction over international crimes and a

1 Sarah Viau (M.A.) is an LL.B. candidate at Queen's University.

${ }^{2}$ Felix S. Cohen, "Human Rights: An Appeal to Philosophers," in Edel, Flower, and O’Connor (Eds.), Morality, Philosophy, and Practice, p. 596.

${ }^{3}$ It is worth noting that there are also debates both about the meaning of these terms, as well as whether or not a particular act fits within a given definition. For example, Slobodan Milosevich might very well agree that genocide is wrong and that perpetrators must be held accountable, while maintaining that no such acts were committed under his rule (i.e. he could argue that they were acts of self-defence). Hitler, in contrast, seemed to believe that genocide was not only acceptable, but could be justified.

${ }^{4}$ Richard A. Falk, Human Rights Horizons, p. 182. 
mandate to hold perpetrators of human rights abuses accountable for their actions. As such, the Court can be seen as a declaration that certain behaviour will not be tolerated by the international community, and that individuals will be held accountable for violating these standards. As Lord Hutton commented in his decision in the Pinochet case,

since the end of the second world war there has been a clear recognition by the international community that certain crimes are so grave and so inhuman that they constitute crimes against international law and that the international community is under a duty to bring to justice a person who commits such crimes. ${ }^{5}$

But what is the source of such a duty, and how does this relate to the concept of jurisdiction? What is the jurisdictional basis of the International Criminal Court?

There are essentially two different models of jurisdiction: a territorial model, and a subject-matter model. William B. Simons outlines a "territorial triangle model" of jurisdiction which purports to identify the necessary and sufficient conditions for the exercise of jurisdiction. Simons notes that, traditionally, the concept of jurisdiction has been represented by a triangular model, consisting of specific relationships between the two parties to the dispute, and, at the apex, the state. Simons' claims that a "territorial triangle between the state seeking to establish liability, the accused, and the victim(s)... [is] recognized by international law as sufficient to establish jurisdiction." ${ }^{6}$ These three components of this "territorial jurisdictional triangle" have therefore been regarded as the necessary and sufficient conditions to establish jurisdiction.

Alternatively, the subject-matter model of jurisdiction looks to the nature of the crime to trigger the exercise of jurisdiction, and does not depend on any territorial linkages. In this paper, I argue that the International Criminal Court is based on a subject-matter model of jurisdiction,

\footnotetext{
${ }^{5}$ Lord Hutton, Reg. v. Bow Street Metropolitan Stipendiary Magistrate, Ex parte Pinochet Ugarte (No. 3), p. 56, para. 192, March 24, 1999.

6 William B. Simons, "The Jurisdictional Basis of the International Military Tribunal at Nuremberg," in George Ginsburgs and V.N. Kudriavtsev, The Nuremberg Trial and international Law, p. 43-4.
} 
representing a commitment to a certain standard of behaviour and set of values (manifest in the types of crimes it addresses), and to holding perpetrators accountable for the commission of crimes that violate these values. This raises two different but related sets of questions. First are questions about the exercise of jurisdiction over individuals on the international level; the Court rests on a broad conception of the legal identity of individuals in the international arena, and so raises questions about the basis of this legal identity. The second set of questions focuses on the basis for this standard of behaviour and shared values. Does this indicate that there is a moral component inherent in the law, or can it be explained in purely formalistic terms? Which legal questions are included in this model of jurisdiction?

Ultimately, I will argue that there are three bases on which the subject-matter model of jurisdiction depends: the heinous nature of the crime, its widespread impact, and the need to provide a more just and efficient method of holding perpetrators accountable.

As I will demonstrate, this is premised on two claims: first, inherent in the notion of humanity are fundamental rights which imply obligations to act or refrain from certain actions, and these rights and obligations that individuals have in relation to other individuals by virtue of their shared humanity trump a citizen's rights to its state. This notion of humanity forms the basis of an international legal identity of individuals who can now be parties to these legal disputes. Second, a commitment to the rule of law includes a commitment to a certain standard of behaviour, violations of which threaten the integrity of the law; as such, crimes within the jurisdiction of the Court are not only morally condemned, they undermine the fundamental legality of the system in which they occur. Therefore, in the jurisdictional triangle, this notion of humanity and the commitment to the rule of law are what connect the parties, the crime, and the entity seeking prosecution. 


\section{The Rome Statute of the International Criminal Court}

In 1992, the United Nations General Assembly charged the International Law Commission, the body responsible for the codification and development of international law, with drafting a statute for a permanent international criminal court. The International Law Commission submitted a first draft statute in 1993, and a second in 1994, and an Ad Hoc Committee created to review the draft statute met twice in 1995. A Diplomatic Conference convened in Rome from June 15, 1998 to July 17, 1998 to finalize the statute and culminated in the signing of the Rome Statute of the International Criminal Court on July 17, 1998. On April 11, 2002, the International Criminal Court received its $60^{\text {th }}$ ratification - the number of ratifications needed to validate the Statute - and is expected to officially come into force in 2003.

The Rome Statute articulates the structure and functioning of the International Criminal Court, and provides for its establishment as a body of the United Nations. Although the International Criminal Court will not operate on a strict sense of universal jurisdiction, its jurisdictional basis represents a radical shift from the traditional model in at least two important respects. The first difference is that the Court will exercise jurisdiction over individuals on the international level. In other words, even though the principles of extraterritorial jurisdiction presuppose the involvement of multiple states, the actual prosecution occurs in domestic courts, and the perpetrator is subject to domestic sanctions. The second radical shift is that the Court severs the territorial link that forms an essential part of Simons' territorial triangle model of jurisdiction. Although States play an important role in that ratification of the Rome Treaty gives the Court jurisdiction over its nationals, there are complex provisions for exercising jurisdiction over individuals from Non-Party States based on the inability or unwillingness of the Non-Party State to prosecute. 
These shifts in the exercise of jurisdiction in the international arena can be seen more clearly by comparing the International Criminal Court with other international legal entities. For example, the difference between the International Criminal Court and the International Court of Justice is essentially related to their jurisdictional capacities. As Simons' model illustrates, one of the pieces of jurisdiction is the notion of 'parties' - those who can appear before the court. States are the only parties that can be heard by the International Court of Justice. Since individuals cannot appear before the Court, problems of territoriality related to the exercise of jurisdiction are avoided. Further, the members of the International Court of Justice vote in each case to determine, by principles of international law, whether the Court can claim jurisdiction. ${ }^{7}$ In this respect, the agreement piece is fulfilled, since states are only parties to the disputes for which they accept the authority of the International Court of Justice to exercise jurisdiction. The jurisdiction of the International Court of Justice thus fits within Simons' territorial triangle model.

Similarly, the International Covenant on Civil and Political Rights includes an Optional Protocol which authorizes individuals to bring complaints against their government for violating their human rights to the United Nations Human Rights Committee. ${ }^{8}$ However, individuals can only bring actions against their own state, and only after having exhausted all other domestic legal remedies. Additionally, the state must be a signatory to the Optional Protocol; in other words, the state must allow its citizens a mechanism for holding it accountable. The Committee represents a change in the model of jurisdiction in that individuals can be parties to the dispute.

\footnotetext{
${ }^{7}$ Giorgio Gaja, "Deliberating on Questions of Jurisdiction in the International Court of Justice," in Nisuke Ando et al. (Eds.) Liber Amicorum Judge Shigeru Oda, p. 409-417.

${ }^{8}$ The Optional Protocol entered into force on March 27, 1976, and in August 1977, the Human Rights Committee began considering individual cases. See Nisuke Ando, "The Follow-up Procedure of the Human Rights Committee' s Views," in Nisuke Ando et al. (Eds.), Liber Amicorum Judge Shigeru Oda, p. 1437.
} 
As such, this is a step up from the International Court of Justice in that it offers a mechanism for individuals to be parties to disputes against the state. However, the jurisdictional basis of the Human Rights Committee also fits within Simons' territorial triangle model, since an individual can only bring an action against her own state, and the state must accept the authority of the Committee, thereby preserving the territorial link. Further, since the Human Rights Committee is a United Nations organization, it lacks an effective means of actively remedying the claims of violations of human rights that are brought before it. The Committee merely issues a statement of its "views" in the form of a letter to the state if found guilty of violating the human rights of its citizens. ${ }^{9}$ Because it has no real practical impact on the state, the Committee does not raise jurisdictional issues in the same way as the International Criminal Court.

The International Criminal Court extends individual legal identity, and, as an international tribunal, promises to be more effective, having procedures in place to hold individuals accountable in meaningful ways. There are four features of the Statute which illustrate the fundamental differences between the International Criminal Court and other international legal entities. First, the statute sets out the "substance jurisdiction" of the Court. There are four categories of crimes within the Court's jurisdiction: genocide, crimes against humanity, war crimes, and crimes of aggression. Although it is not necessary to elaborate on the details of these crimes, it is important to note the types of crimes in question, as it provides insight into the purposes of the court: to indicate the standards of behaviour applicable to every individual by virtue of their humanity; and to uphold the values of the international community. Therefore, what legitimates the Court's exercise of jurisdiction is the heinous nature of these crimes.

\footnotetext{
${ }^{9}$ Nisuke Ando, "The Follow-up Procedure of the Human Rights Committee's Views," in Nisuke Ando, Liber Amicorum Judge Shigeru Oda, p. 1437-1447
} 
Second, Article 15 of the Statute defines the situations when the Court can legitimately exercise its authority, articulating the Court's jurisdiction with respect to national criminal law systems. This question is answered by the principle of complementarity, a central concept of the Court, as well as one of the most significant features of the Statute that has led to its success. This principle holds that the Court will complement, not replace, national courts. Thus, a case is inadmissible when a state has already initiated an investigation, unless the state is "unwilling or genuinely unable" to carry out the investigation or prosecution. In addition, a case is inadmissible when it has been investigated and a person convicted, or when the state has decided not to prosecute; in both cases, however, the Court can step in if it is determined that the decision was the result of "unwillingness or genuine inability" to prosecute. It is worth noting that, even though the Statute also provides a set of criteria for determining unwillingness and genuine inability, such determinations are made by the Court.

The Statute also identifies the four different entities which have the authority to initiate an investigation or proceeding: a State Party to the Treaty; the State in which the crimes took place; the UN Security Council; or the prosecutor for the International Criminal Court. Because the Court is treaty-based, the effect on sovereignty is intended to be minimal; the court is intended to have jurisdiction over individuals from member states - i.e. states who have freely accepted that certain crimes or circumstances justify a limitation on their sovereignty. However, there are also complex arrangements whereby Non-Party States can grant the Court jurisdiction over its nationals. For example, a Non-Party State could grant the Court jurisdiction over a particular incident. This means that individual legal identity can be extended retroactively. The purpose of these articles is to fulfill the requirement that parties to the dispute accept the authority of the Court. However, the agreement is sought through the state, and not directly from 
individuals. This both extends and obscures individual legal identity, since nationals of States Parties are clearly subject to the jurisdiction of the Court, while other individuals do not have this element of certainty about the legal entities to whom they can expect to be held accountable. This can negatively affect the legitimacy of the Court, since one of the principles of the rule of law is that the laws to which individuals are subject must be publicly promulgated.

The fourth relevant aspect of the Rome Statute, which is another significant achievement, is the codification of the principles of international criminal law. In fact, it is the first international instrument to articulate the general principles of criminal law that are contained in most national legal systems. Part Three of the Statute is devoted entirely to these principles, four of which are particularly relevant to the present discussion. First, Article 22 establishes the principle of nullen crimen sine lege, which means that there can be no crime without law; in other words, a person can only be held criminally responsible for a crime that is expressly included in the Statute. A second and related principle is contained in Article 23: nulla poena sine lege, which requires that the penalties to be imposed must be contained within the law. ${ }^{10}$ Article 24 articulates the principle of non-retroactivity ratione personae, meaning that a person cannot be held criminally responsible under the statute for conduct prior to the entry into force of the Statute. ${ }^{11}$ This principle gave rise to an interesting debate over the appropriate verb to be attached with the term "conduct" - whether it should be conduct "committed," "occurred," "commenced," or "completed." This debate was the result of a debate over the deeper issue of how to address "continuous crimes" - crimes that are being committed before the establishment of the Court, and that would continue after the Court is established. For example, one element of

\footnotetext{
${ }^{10}$ Per Saland, "International Criminal Law Principles," in Roy S. Lee, The International Criminal Court: The Making of the Rome Statute, p. 194-6.

${ }^{11}$ Ibid., p. 196-7.
} 
the crime of genocide is that "the perpetrator intended to destroy, in whole or in part, that national, ethnical, racial or religious group, as such." ${ }^{12}$ If the Court is to have jurisdiction over crimes committed only after the ratification of the Statute, then this raises the question of whether or not perpetrators of genocide before the establishment of the Court who have not yet completed their crime can be brought before the court.

The fourth relevant principle is expressed in Article 25; the principle of individual criminal responsibility establishes that the Court will have jurisdiction over natural persons ${ }^{13}$, and a person (not the state) who commits a crime under the Statute is individually responsible and liable for punishment. ${ }^{14}$ In order to preserve state sovereignty, this Article declares further that this principle in no way affects the scope of the authority of states. States are still responsible for protecting their territory, and nothing in the Rome Statute prevents states from engaging in legitimate warfare; rather, it sets the rules of international warfare and the limits of domestic authority. ${ }^{15}$ The difference is that the Court establishes a second entity endowed with its own set of responsibilities, including the responsibility to hold individuals accountable even in instances where the state will not. Therefore the Rome Statute significantly extends individual legal identity to the international arena, virtually relinquishing the connection with the state that

${ }^{12}$ William A. Schabas, An Introduction to the International Criminal Court, p. 249.

${ }^{13} \mathrm{An}$ issue still being debated is whether or not the Court should have jurisdiction over other legal entities, like corporations. Although this is a fascinating and important debate, I will not discuss the matter further in this paper.

${ }^{14}$ Per Saland, "International Criminal Law Principles," in Roy S. Lee (Ed.), The International Criminal Court: The Making of the Rome Statute, p. 198-200.

${ }^{15}$ At this point, it will be instructive to take note of some relevant distinctions between the International Criminal Court and other international tribunals. For example, objections to the Nuremberg and Tokyo tribunals were raised on the grounds that they violated three principles of international law: no law, no crime; no law, no punishment; and non-retroactive law-making. These principles have become enshrined in the Rome Statute, which has been worked out to resolve these problems. Although the International Criminal Tribunal for the Former Yugoslavia, and the International Criminal Tribunal for Rwanda may also be able to escape these objections, they are ad hoc tribunals established at the end of the Cold War, and have limited territorial and temporal jurisdiction, unlike the ICC which will be established as a permanent court with a much broader territorial jurisdiction. Further, the International Criminal Court will be somewhat less powerful then these two ad hoc tribunals, because the ICTY and the ICTR have concurrent jurisdiction with national courts and may exercise primacy over them. 
has traditionally been considered as a prerequisite for the exercise of jurisdiction. But if this is true, then what is the basis of this individual legal identity?

\section{An International Legal Identity Independent of States}

Genocide, war crimes, and crimes against humanity are among the most heinous crimes to have been witnessed by the international community. Because these crimes are committed by individuals, not states, the International Criminal Court presupposes jurisdiction over individuals. ${ }^{16}$ The question is whether the Court maintains an individual legal identity that is still directly tied to the state, or establishes an international legal identity which is completely independent of states. The second option would give the Court jurisdiction over all individuals, regardless of whether they are citizens of a state that is not Party to the Rome Statute and that rejects the authority of the Court. According to the first possibility, on the other hand, the Court would only have jurisdiction over individuals from states who are Party to the Rome Statute, or who accept the jurisdiction of the Court over a particular situation. This option does not establish a second level of legal identity, and affirms the primacy of state sovereignty. It is this model which forms the basis of the international legal identity created for individuals in The Rome Statute. Since the structure and functioning of the International Criminal Court is articulated by a Statute, its existence depends on the agreement of states, which comes in the form of ratification. The Statute provides that states incorporate international criminal laws within their domestic authority structures, and accept the legitimacy of the Court of which it is a part.

That states are required to ratify the Statute before the Court can commence operations

\footnotetext{
$16 " .$. ' the state' does not violate human rights without the intervention of some human agency...," Christopher Gane and Mark Mackarel (Eds.), Human Rights and the Administration of Justice: International $\underline{\text { Instruments, }}$ p. xxxvi.
} 
seems to imply a territorial model of jurisdiction. But it is questionable whether this is really an accurate portrayal of the jurisdictional basis of the Court. The motivation behind the Court is the general abhorrence of certain crimes and the need to develop a mechanism to hold perpetrators accountable; therefore, it seems to be that it is the nature of the crime that serves as the source of acceptance of the Court's authority. In addition, the complex procedures for extending the Court's jurisdiction imply that the connection to the state is not as fundamental as it first appears, and so there is a sense in which the Court does create an individual legal identity independent of states.

The problem with a legal identity independent of states lies in ascertaining the source of this identity. States can accept the claim that they have jurisdiction over their own nationals for international crimes, because jurisdiction is justified by a link to the state, thereby fitting nicely within the framework of the sovereign state system and the territorial triangle model. An individual legal identity independent of the state rejects the link with the state; but in doing so, it raises important questions: What occupies the apex of the territorial triangle model? What justifies the exercise of jurisdiction over any individual, anywhere?

The answer to these questions requires a closer look at the role played by the state in the territorial triangle model. A key feature of jurisdiction, which is nicely illustrated by the territorial triangle model, is the element of agreement: the parties to the dispute must accept the authority over the entity claiming jurisdiction in order for them to accept its judgments as binding. Thus, the element of agreement is a characteristic concern of any jurisdiction, and in the territorial model, this is provided by the state. Therefore, it seems that, by making the agreement piece explicit, the triangular model does grasp a crucial feature of the concept of jurisdiction. The question is thus whether the state must always be at the apex of the triangular 
model. If the territorial link is abandoned, then, something else must occupy the apex - there must be some grounds on which the parties to the dispute will accept the authority of the decision- maker to resolve their dispute.

In order to fill this gap, there must be a connection between the parties (i.e. individuals), the crimes (i.e. genocide, war crimes, and crimes against humanity), and the authoritative decision-maker (i.e. the Court). Thus, the International Criminal Court forces the issue of the justification for criminalizing these acts. The justification can not be that the international community as a whole accepts that these crimes are wrong, because, as both history and the present clearly show, this is not the case. In the following section, I argue that there is a specific content to the notion of humanity that demands a certain minimal level of protection; in addition, I maintain that a commitment to law also indicates a commitment to a certain standard of behaviour, such that there can not be an international legal order built on a commitment to genocide, war crimes, or crimes against humanity. It is this notion of humanity, as well as a commitment to the rule of law that provide the connection between the parties, the crimes, and the authoritative decision-maker in the subject-matter model jurisdictional triangle.

\section{Humanity, Legality, and the Jurisdictional Triangle}

As previously discussed, the crimes over which the International Criminal Court will have jurisdiction are war crimes, genocide, and crimes against humanity. This list probably does not include piracy and slavery because these crimes are accepted as crimes over which states can exercise universal jurisdiction. Interestingly, they are also crimes which are committed with much less frequency. In contrast, war crimes, genocide, crimes of aggression, and crimes against humanity are still included in many state policies. This raises the question, what do these crimes have in common that triggers the jurisdiction of the International Criminal Court? Perhaps the 
answer can be found in the effects of these crimes, which have a widespread impact on humanity, producing human suffering, terminating life, and violating human dignity.

Therefore, underlying the very idea of these crimes (especially crimes against humanity) is the notion that there is a common element that unites all individuals, regardless of what territory they happen to be in. This common element is an interest in avoiding suffering, preserving life, and maintaining dignity. According to Richard Falk,

world order has been analyzed for centuries as if human suffering were irrelevant, and as if the only fate that mattered was either the destiny of a particular nation or the more general rise and fall of great powers, the latter being regarded as an inevitable consequence of the eternal, natural rivalry of self-serving states competing for territory, wealth, influence, and status. ${ }^{17}$

Falk is concerned with developing an international response to the challenges of genocidal politics, claiming that the Westphalian system has weakened "a sense of responsibility for human wrongs," particularly because it "open[ed] the way for exclusivist political conceptions of community that were based on race, nation, civilization, and secular ideology, but which did not relate to humanity as a whole." ${ }^{18}$ Similarly, Mary Kaldor argues that the modern nationstate has developed a concept of citizenship which is based on civil and political rights, such that "patriotism linked to a notion of rights became the primary source of legitimacy." ${ }^{19}$ As such, one of the consequences of the sovereign state system has been the demarcation of boundaries not only between states, but also between individuals, isolating them, perpetuating disputes, and eroding any sense of connection individuals might feel towards others by vir tue of their shared humanity.

According to Falk, "such trends, in turn, encourage disruptive ethnic and exclusivist

\footnotetext{
${ }^{17}$ Richard Falk, Human Rights Horizons, p. 173.

${ }^{18}$ Ibid., p. 175-6.

${ }^{19}$ Mary Kaldor, "Governance, Legitimacy, and Security: Three Scenarios for the Twenty-First Century," in Paul Wapner and Lester Edwin J. Ruiz (Eds.), Principled World Politics, p. 286.
} 
identities that subvert modernist secular and territorial commitments to tolerance and moderation." 20 Further, Falk claims that "sanctifying national flags and other symbols of nationality contributes to hostile stereotypes of 'the other,' encouraging violence and militarism, validating hierarchy, domination, and inequality, and providing an overall facade for virulent, xenophobic patriotism." 21 The point here is that such nationalist tendencies contribute to individuals conceiving themselves primarily as citizens of states or as members of some other type of exclusive group, rather than inclusively, as human beings. This puts primacy on state interests over individual interests, even legitimating the violation of individual interests for the sake of the state. Claims of minority nationalism seem particularly isolationist, as they are invoked by one group of people against another who share the same territory, creating an 'us vs. them' mentality. I do not mean to dismiss nationalism, which admittedly has encouraged the recognition that cultural differences merit prima facie respect, and has even played an important role in making certain universal understandings of rights possible by contributing to a notion of citizens' rights. Rather, I wish to suggest that one negative consequence of the state system has been to drive wedges between individuals by insisting that individuals are primarily citizens of states, and that their interests are secured by securing state interests, complicating efforts at cooperation at the international level.

Falk sees the solution to gross human rights abuses in "the deepening and expansion of democratizing tendencies, making leaders more consistently receptive to international law, and to the guidelines spelled out in the main human rights instruments, ${ }^{22}$ and argues that the construction of a global morality premised on a universal conception of human rights is essential

\footnotetext{
${ }^{20}$ Richard Falk, Human Rights Horizons, p. 176.

${ }^{21}$ Ibid., p. 177.

${ }^{22}$ Ibid., p. 183.
} 
for overcoming the difficulties associated with globalization. Falk's conception of human rights on which he bases this global morality is unique in that it establishes responsibilities as necessary and equally important correlatives of rights. Falk argues that

responsibilities must be conceived as correlative to rights. Such a premise would be well served by the drafting of a Universal Declaration of Human Responsibilities as an indispensable companion to the Universal Declaration of Human Rights. ... The notion of protecting the individual is a great advance over its absolutist antecedents, but it needs to be balanced by the acknowledgment that the individual is embedded with a community. ${ }^{23}$

Interestingly, one of the prerequisites for recognition as a sovereign state by the international community is a signature on the United Nations' Universal Declaration of Human Rights, ${ }^{24}$ which is essentially a declaration of moral equality that is meant to apply to all people regardless of their state of citizenship. ${ }^{25}$ As a declaration signed by states, it implies that states are responsible for ensuring that citizens abide by the terms of this agreement, thereby recognizing and affirming state sovereignty as the source of jurisdiction. Falk would extend this to imply that all individuals have a responsibility to refrain from violating the human rights of others, giving the concept 'human' has a definite substance, grounded in the human interests to avoid suffering, preserve life, and maintain dignity. ${ }^{26}$

\footnotetext{
${ }^{23}$ Ibid., p. 88.

${ }^{24}$ Universal Declaration of Human Rights, adopted 10 Dec. 1948, G.A. Res. 217A (III), 3 U.N. GAOR (Resolutions, part 1) at 71, U.N. Doc. A/810 (1948).

${ }^{25}$ Stephen D. Krasner, Sovereignty: Organized Hypocrisy, p. 106.

${ }^{26}$ I do not wish to join Falk in promoting the "Human Responsibilities Movement," a movement motivated by a perceived imbalance between rights and responsibilities; rather, my discussion of Falk' s insistence on the connection between rights and responsibilities is meant to point out that, inherent in the notion of a human right is a corresponding duty of the claimant of such a right to recognize that everyone else has that same right simply by virtue of their humanity. This recognition does not necessarily require the creation of an international human duties document, as Falk suggests. For example, in Ben Saul's critique of the Human Responsibilities Movement, he notes that "human rights law already adequately recognizes a range of express, implied, correlative, regional, and emergent human duties, obligations, and responsibilities." In fact, one of Saul's main concerns about this movement is that "the human rights movement originated in struggles against traditional forms of duty towards the church, feudal lords, and the monarchy." Ben Saul, "In the Shadow of Human Rights: Human Duties, Obligations, and Responsibilities," p. 565-622.
} 
I argue that this notion of humanity is the basis of international legal identity of individuals created by the International Criminal Court; this provides insight into the connection between individuals (parties) and the crimes in the subject-matter model of jurisdiction. This notion of humanity sets standards of human behaviour in the form of rights and responsibilities which indicate that certain types of behaviour are unacceptable - are criminal - simply by virtue of their effects on humanity. This normative component uncovers an important connection between Falk and legal philosopher Lon Fuller. Fuller insists that the very concept of law contains a moral component, and as such, advocates a universal morality, at least in the context of the law. Fuller's account of the nature of law could be extended to accommodate the claim that, in addition to formal requirements, there are certain standards of behaviour inherent in the law that must be upheld in order to legitimate a system of law. Falk claims that "there is a continuous moral pressure to make law into a vehicle for the realization of moral goals ... implying that these actors have a moral duty to uphold international law, and that the law, in effect, embodies authoritative standards of morality." ${ }^{27}$ Therefore, it seems that the subjectmatter model of jurisdiction is based on the claim that there is a moral component in the concept of legality that sets certain standards of behaviour which, if violated, undermine the integrity of the system.

But, is there another way to conceive of the relationship between the parties and the crimes in the subject-matter model of jurisdiction? Is there something else in the nature of law which indicates that there can not be an international legal system that permits states to operate with a mandate of genocidal politics? In her discussion of global governance for the $21^{\text {st }}$ century, Mary Kaldor makes some interesting connections between the concepts of governance,

\footnotetext{
${ }^{27}$ Ibid., p. 219.
} 
legitimacy, and security. According to Kaldor, "central to the future of governance is the provision of security, which ... is inextricably bound up with legitimacy." ${ }^{28}$ Kaldor defines security as "the control of organized violence ... includ[ing] the security of the individual and not just the state." 29 Legitimacy she defines as

the extent to which people consent to and even support the framework of rules within which political institutions function, either because political institutions are viewed as having gained their authority through some legitimate process and/or because they are seen to represent ideas or values that are widely supported. ${ }^{30}$

With these definitions, Kaldor argues that

the control of organized violence is an essential precondition for effective governance. It is inseparable from another essential precondition: legitimacy. On the one hand, the ability to maintain order, to protect individuals in a physical sense, to guarantee the operation of justice and the rule of law, are the primary functions of institutions from which they derive their legitimacy. ... On the other hand, it is not possible to provide security in the sense just defined without some underlying legitimacy. There has to be some mechanism ... that explains why people obey rules. ${ }^{31}$

Therefore, central to the legitimacy of a legal system is its ability to provide individuals with security, and its ability to effectively guide behaviour will depend on the degree of security it provides.

Kaldor' s argument takes for granted that law is an institution established to guide behaviour in such a way as to provide individuals with the security to live in peace with others. Kaldor's picture of law does not depend on a fundamental connection between law and morality; rather, both conceive of law as being purposive. As such, the subject-matter model of jurisdiction can link the parties to the crimes by virtue of their impact on the law's ability to

\footnotetext{
${ }^{28}$ Mary Kaldor, "Governance, Legitimacy, and Security: Three Scenarios for the Twenty-First Century," in Paul Wapner and Lester Edwin J. Ruiz (Eds.), Principled World Politics, p. 284.

${ }^{29}$ Ibid., p. 284-5.

${ }^{30}$ Ibid., p. 285.

${ }^{31}$ Ibid., p. 285.
} 
fulfill its purposes of guiding behaviour and providing security. Allen Buchanan agrees that, "especially in liberal societies, which tolerate and even promote pluralism, whatever it is that legitimates the system of legal rules, it cannot be shared substantive ends or even a shared conception of justice." 32 However, Buchanan asserts that although there may be fundamental disagreements among members of domestic societies, there are essential values shared by the international community:

international legal institutions, as well as the forces of economic globalization, have contributed to the development of a transnational civil society in which a culture of human rights is emerging. This culture of human rights is both founded on and serves to extend a shared conception of the minimal institutional arrangements needed to protect them.",33

As Falk notes, "[the application of morality to international political behavior] is conditioned by various assumptions about human nature, both as it happens to be intellectually conceived at a given moment, and as defined by decisive historical experiences." ${ }^{34}$ Kaldor ultimately argues that Richard Falk articulates the best approach to providing security: "in the Falk vision, political legitimacy has to be reconstructed around the principles of humanity - a universalistic goal of comprehensive rights for everyone and the elimination of war." ${ }^{\text {" }}$ If the law can be defined in terms of what it requires to fulfill its purposes, and if the law's purposes are partly determined by the human condition, then in the context of globalization, which describes the contemporary human condition, it seems that the ability of law to fulfill its purposes is going to depend on a commitment by the international community to a shared set of values, manifest in this culture of human rights.

\footnotetext{
${ }^{32}$ Allen Buchanan, "From Nuremberg to Kosovo: The Morality of Illegal International Legal Reform," Ethics, p. 690.

33 Ibid., p. 691.

${ }^{34}$ Richard. A. Falk, Human Rights Horizons, p. 219.

${ }^{35}$ Mary Kaldor, "Governance, Legitimacy, and Security: Three Scenarios for the Twenty-First Century," in Paul Wapner and Lester Edwin J. Ruiz (Eds.), Principled World Politics, p. 296.
} 


\section{Objections to the International Criminal Court}

The increase in the commission of crimes that are not contained with national borders, coupled with the inability or unwillingness of states to prosecute perpetrators of these crimes, seem to necessitate the establishment of a legal entity capable of providing effective resolution of these issues. However, there exists strong opposition to the International Criminal Court in the international community. In this section, I will outline these objections, showing that they are essentially objections to the subject-matter model of jurisdiction.

The obstacles to the establishment of the International Criminal Court are largely a result of the permeation of realist theories of international relations. The realist position rejects the possibility that there are any universal standards of morality, and insists that the international community is driven by state interests. Allen Buchanan explains that, "according to the Realist theory, the structure of international relations precludes moral action except where it happens to be congruent with state interest. The importance of creating norms by state consent, on this view, is that it provides a way for states, understood as purely self-interested actors, to promote their shared long-term interests in peace and stability." ${ }^{36}$ Falk adds that "the established order, realists argued, can be protected only by military means, and in this sense, legal and moral rules of prohibition are futile, and even dangerous to the extent that they induce complacency. ${ }^{37}$ The Realist position assumes that

the members of the so-called community of states are moral strangers, that the state system is a mere association of distinct societies that do not share substantive ends of a conception of justice, rather than a genuine community. In the absence of shared substantive ends or a common conception of justice,

\footnotetext{
${ }^{36}$ Allen Buchanan, "From Nuremberg to Kosovo: The Morality of Illegal International Legal Reform," Ethics, p. 689.

${ }^{37}$ Richard Falk, Human Rights Horizons, p. 224.
} 
consent is the only basis of legitimacy for a system of norms. ${ }^{38}$

Contemporary realist and former United States Secretary of State, Henry Kissinger, is strongly opposed to both the establishment of an International Criminal Court and the exercise of universal jurisdiction. He makes four main objections: first, Kissinger condemns the "extraordinary attempt of the ICC to assert jurisdiction over Americans even in the absence of U.S. accession to the treaty." 39 In his response to Kissinger' s article, Kenneth Roth notes that, "the United States itself asserts such jurisdiction over others' citizens when it prosecutes terrorists or drug traffickers ... without the consent of the suspect' s government." ${ }^{40}$ One has to question why Kissinger would be more concerned that an American might be tried by foreign authorities for the commission of heinous crimes, rather than with the implication that an American would commit such crimes.

Secondly, Kissinger claims that the Court "represents such a fundamental change in U.S. constitutional practice, ${ }^{41}$ that if it asserted jurisdiction over an American, it would violate the U.S. constitution. However, as Roth notes, in order for the Court to assert jurisdiction over an American, it would be because "an American committed genocide, war crimes, or crimes against humanity on U.S. soil; and then U.S. authorities did not prosecute the offender ... [which] would signal a constitutional crisis far graver than one spawned by an ICC prosecution. " ${ }^{42}$

Thirdly, Kissinger is concerned about the potential politicization of the Court, and that it would "permit the two sides in the Arab-Israeli conflict, or those in any other passionate Ethics, p. 689.

${ }^{38}$ Allen Buchanan, "From Nuremberg to Kosovo: The Morality of Illegal International Legal Reform,"

${ }^{39}$ Henry Kissinger, "The Pitfalls of Universal Jurisdiction," Foreign Affairs, p. 94.

${ }^{40}$ Kenneth Roth, "The Case for Universal Jurisdiction," Foreign Affairs, p. 152.

${ }^{41}$ Henry Kissinger, "The Pitfalls of Universal Jurisdiction," Foreign Affairs, p. 93.

${ }^{42}$ Kenneth Roth, "The Case for Universal Jurisdiction," Foreign Affairs, p. 153. 
international controversy, to project their battles into the various national courts by pursuing adversaries with extradition requests." ${ }^{43}$ This is a cynical perspective of court officials, and as Roth notes, "the experience of the Yugoslav and Rwandan tribunals ... suggests that international jurists, when forced to decide the fate of a particular criminal suspect, do so with scrupulous regard for fair trial standards." ${ }^{44}$

Kissinger' s most compelling argument is that allowing states to resolve disputes within its own territory "mak[es] it possible to deal with the charges against [offenders] in the courts of the country most competent to judge this history and to relate its decisions to the stability and vitality of its democratic institutions." ${ }^{45}$ But this support of attempt at "national reconciliation" ignores the degree to which "democratic" systems are unwilling or unable to address genocide, war crimes, or crimes against humanity, especially when they implicate heads of state.

Christopher Hitchens, in his recent book, Trial of Henry Kissinger, argues that Kissinger is himself a war criminal, and should be prosecuted for war crimes committed during various United States military operations, including: war in Indochina; mass murder in Bangladesh; planned assassinations in Santiago, Nicosia, and Washington, D.C.; and genocide in East Timor. ${ }^{46}$ As such, Hitchens claims that Kissinger is a prime candidate for prosecution by an international court. Are Kissinger' s objections merely out of self-interest, denouncing universal jurisdiction and the International Criminal Court out of fear of his own prosecution? I argue that underlying Kissinger' s objections is a conception of non-Americans as less than human, and a presumption of American superiority which justifies any American policy. Americans, as well

\footnotetext{
${ }^{43}$ Henry Kissinger, "The Pitfalls of Universal Jurisdiction," Foreign Affairs, p. 92.

${ }^{44}$ Kenneth Roth, "The Case for Universal Jurisdiction," Foreign Affairs, p. 152.

${ }^{45}$ Henry Kissinger, "The Pitfalls of Universal Jurisdiction," Foreign Affairs, p. 90.

${ }^{46}$ Christopher Hitchens, Trial of Henry Kissinger.
} 
as nationals of other states, identify themselves as members of states, and as having primary responsibilities to the state, rather to others by virtue of their humanity. According to Falk, "any genuine alternative, then, to realist morality must be predicated upon a comprehensive vision of global security." ${ }^{47}$ In other words, it must be premised on the claim that there is an element inherent in the notion of humanity that implies certain rights by virtue of this humanity, and that the individual - not the state - comes first in the international community. However, this perspective of the primacy of the individual as a human with rights and responsibilities raises problems for the sovereign state system.

\section{The International Criminal Court and the Sovereign State System}

The impact of the International Criminal Court on state sovereignty is directly related to jurisdictional issues. Can a sovereign state surrender its sovereign responsibility to prosecute and enforce certain crimes, or in certain circumstances, without surrendering sovereignty in its entirety? In other words, is the International Criminal Court, operating on a subject-matter model of jurisdiction, which does not rely on any territorial connection, compatible with the current system of international relations?

Underlying the subject-matter model of jurisdiction of the International Criminal Court is a commitment to the rule of law and a conception of the individual as having certain rights and responsibilities by virtue of his humanity. The Court can thus be seen as a shift among the members of the international community, toward a "pre-Westphalian" mentality, in which the members of the international community reject realist assumptions and are more willing to

\footnotetext{
${ }^{47}$ Richard Falk, Human Rights Horizons, p. 227.
} 
cooperate in order to address heinous crimes. This raises the question of whether the concept of sovereignty should be modified to accommodate the International Criminal Court, or whether the subject-matter model of jurisdiction of the Court represents a foundation on which to build a new international legal order. John Hoffman argues that, in order for the concept of sovereignty to make sense in the modern political landscape, it must be detached from the state. Such a conception can focus on "the individual as a collectivity of relationships," 48 and on the relational concept of government, since it operates on the assumption that "individuals acquire their freedom and autonomy through their relations with others [rather that through the state]." 49 Perhaps, then, the international institutional structure can be remodelled on the international community' s commitment to universal human rights; such a commitment establishes a rightduty relationship between states and their citizens, but it is conceivable that a similar right-duty relationship could be forged between peoples, without relying on the state. As Buchanan notes,

the canonical language of the major human rights documents indicates a tendency toward convergence that may be as good a candidate for a core shared conception of justice as that which Rawls attributes to liberal societies: the idea that human beings have an inherent equality and freedom. ${ }^{50}$

Therefore, perhaps if the concept of sovereignty is modified so as to define a right-duty relationship not only between states, but also between individuals, whereby individuals have rights and duties to each other by virtue of their humanity that are accompanied by sanctions for violations of these rights or duties. One of these state duties would include the duty to prosecute its citizens for violations of human rights, and an international court would be required only to intervene when states refuse or are unable to fulfill their duties. Such an international authority

\footnotetext{
${ }^{48}$ John Hoffman, Sovereignty, p. 86-107.

${ }^{49}$ Ibid, p. 86-107.

${ }^{50}$ Allen Buchanan, "From Nuremberg to Kosovo: The Morality of Illegal International Legal Reform," Ethics, p. 691.
} 
would require a definable set of rights and duties in order to provide a justification for states to make claims against individuals, rights and duties that arise out of a particular notion of humanity and a commitment to the rule of law. If this is what the Rome Statute is intended to provide, then perhaps the international community is moving toward replacing the sovereign state system with a version of a right-duty relationship as the basis for these claims.

The sovereign state system is structured so as to perpetuate power struggles between states. It is important to recognize that the sovereign state system does not reproduce itself those in charge do. The state system confers an enormous amount of power on those who happen to be in charge, providing a substantial incentive to maintain the state system, and refuse to allow an external authority to exist which may take away some of that power. Further, there are many benefits associated with sovereignty; because attaining sovereign status is largely dependent on recognition by the international community (i.e. the other sovereign states), states can apply pressure on those seeking statehood in a variety of different ways. For example, one criteria for membership in the international community - for recognition as a sovereign state - is being a signatory to the United Nations' Universal Declaration of Human Rights. As such, pressure can be placed on governments to sign the Declaration. However, sovereignty can be and has been used by non-democratic (even by supposed democratic) states to justify, rather than address violations of human rights. The United Nations, which endeavours to address such human rights violations, simultaneously affirms the legitimacy of the sovereign state system. The problem with this is that states can use their sovereign status to claim authority over determining the scope of human rights within their jurisdiction. Although the United Nations can, in some cases, require states to sign international treaties, which have been used to establish international law, sovereignty gives individual states complete responsibility to enforce 
international law. But if states sign treaties with no intention to comply with them, then the lack of an external entity capable of intervening in the domestic authority structures of the state, which would constitute a violation of sovereignty, means that there is no body that is capable of enforcing those treaties, and international law is merely symbolic, or worse, a political weapon. As such, achieving and maintaining meaningful compliance to international agreements does not seem possible without an effective means of enforcing those agreements.

\section{Summary and Conclusions}

This paper has been motivated in large part by seemingly widespread inability and unwillingness of the international community to effectively and legally address the commission of atrocities in an increasingly global society. As Bassiouni and Blakesley note,

the need to develop an international criminal code and an international criminal court is indispensable in the context of the transient nature of international society, the sophistication and transnational nature of modern crime, and the everincreasing interdependency of the new, international world order. As the world becomes a smaller place, the various parts and peoples are more interdependent and more concerned with the same problems of international and transnational criminality. Therefore, greater cooperation and coordination are required. ${ }^{51}$

One can not help but wonder why there has been so much difficulty in attaining cooperation and coordination on these matters. Through the principle of non-intervention, the sovereign state system has created a space in which not only criminal and terrorist groups, but state leaders feel comfortable, and even consider themselves justified in committing heinous acts, because they do so in the name of the state. As such, there is a need to explore ways in which the perpetrators of such atrocities can be held accountable for their actions without threatening to undermine the system, which is the motivation behind the International Criminal Court.

\footnotetext{
${ }^{51}$ M. Cherif Bassiouni and Christopher L. Blakesley, "The Need for an International Criminal Court in the New International World Order," in John Dugard and Christine van den Wyngaert (Eds.), International Criminal Law and Procedure, p. 402-3.
} 
In this paper, I have attempted to give a comprehensive account of the jurisdictional basis of the International Criminal Court. I argued that, even though it is a treaty-based tribunal, implying a necessary territorial connection, this connection is not an essential justificatory element of the exercise of jurisdiction. In the subject-matter model of jurisdiction, the three elements which determine which legal questions fall under its scope are the heinous nature of the crime, the crime's widespread impact, and the ability to provide more just and effective prosecution. The nature of the crime which triggers the exercise of jurisdiction is related to both a conception of humanity as being defined by a shared interest in preserving life, avoiding suffering, and maintaining dignity, as well as to a commitment to the rule of law.

The renewed vigour of the movement toward establishing the International Criminal Court has been closely related to the emergence of an international consensus that human rights are a legitimate component of international law. ${ }^{52}$ However, within the sovereign state system, the application and enforcement of international law is a state responsibility. This has created the need to develop principles legitimating the exercise of extraterritorial jurisdiction to address crimes that are not contained within a single state's boundaries. Subsequently, while the international community struggles with the application of principles of extraterritorial jurisdiction, many gross violations of human rights go unpunished.

I have tried to show that such problems are in large part due to confusion with regard to the concept of jurisdiction. In the sovereign state system, it is taken for granted that a legal system is necessarily tied to a specific geographic location, and so the concept of jurisdiction appears to be nothing more than a feature of sovereignty. This produces a territorial triangle model of jurisdiction, which consists of specific links between the parties to the dispute and the

${ }^{52}$ Sarah B. Sewall, Carl Kaysen, and Michael P. Scharf, "The United States and the International Criminal Court: An Overview," in Sarah Sewall and Carl Kaysen (Eds.), The United States and the International Criminal Court, p.1. 
state claiming authority to resolve the dispute. The problem that I have addressed is that this model can not accommodate crimes which transcend this traditional notion of jurisdiction. This raises the need for a subject-matter model of jurisdiction which is based solely on the nature of the crime, without relying on any connection to the state.

By focusing on the relationship between the parties to dispute and the authoritative decision-maker, the triangle model uncovers an important element of jurisdiction, the element of agreement, which gives the process its legitimacy. What the territorial model fails to grasp, however, is that a defined territory is not an essential element of jurisdiction, and that the nature of the subject- matter provides another way of securing agreement and completing the vertices of the jurisdictional triangle. In the subject-matter model, there are three criteria which determine which legal questions are included: the heinous nature of the crime; the crime's widespread impact; and the ability to provide more just and effective punishment and deterrence. These criteria are derived from both a conception of humanity as being defined in terms of shared interests in preserving life, avoiding suffering, and maintaining dignity which establishes a minimal level of protection for individuals, as well as from a commitment to the rule of law which establishes a minimal standard of behaviour.

Such a model of jurisdiction disregards the principles of state sovereignty and noninterference in the domestic affairs of the state. However, the increasing reality of an emerging global society has prompted a critical attitude toward sovereignty, which has essentially originated from dissatisfaction with the territorial model of jurisdiction attributable to the sovereign state system. The International Criminal Court is an attempt to address these issues, in part by relying on a subject-matter model of jurisdiction. Since the Court is driven by a commitment to holding perpetrators of genocide, war crimes, and crimes against humanity 
accountable, this provides insight into the basis of its subject-matter model of jurisdiction.

According to William A. Schabas, with the establishment of the International Criminal Court, "we have now reached a point where individual criminal liability is established for those responsible for serious violations of human rights, and where an institution is created to see that this is more than just some pious wish. " ${ }^{53}$ But does the establishment of the Court represent a culmination or a beginning? Considered as a new beginning for the international community, by injecting a subject-matter model of jurisdiction into the international arena, the Court may instigate a radical transformation in the structure of international relations. James Crawford notes that one of the difficulties with the establishment of the International Criminal Court is state adherence to their own criminal jurisdiction, while excluding external influences, as a mark of their sovereignty. One radical transformation that may occur, then, is the rejection of the idea that sovereignty necessarily excludes external actors from the domestic authority structures of the state; this, as Crawford admits, is a viable possibility, given the escalating degree to which states cooperate with each other.

Genocide, war crimes, and crimes against humanity have forced the members of the international community to recognize that they share an interest in justice and the rule of law, and that traditional ways of responding to crime are no longer adequate. As such, the International Criminal Court can be seen as a foundation on which to build an international legal and political system that can respond meaningfully and effectively to the challenges of a global community.

Falk urges the acknowledgment "that international relations is a social construction, and

\footnotetext{
${ }^{53}$ William A. Schabas, An Introduction to the International Criminal Court, p. 20.
} 
that its normative emptiness is not a necessity. ${ }^{54}$ But it is up to individuals to infuse international relations with a normative component, and a jurisdictional model based on subjectmatter offers just such an opportunity. However, in the context of international law, the subjectmatter model of jurisdiction consists of more then a moral imperative. The basis of the subjectmatter model of jurisdiction of the International Criminal Court is also based on the recognition that if certain acts are permitted - for example, genocide, war crimes, and crimes against humanity - they violate the principles of the rule of law in such a way as to prevent the law from being able to fulfill its purpose and undermine the international legal order.

Therefore, as we move toward a global society, the integrity of the international system is going to require an authoritative body capable of enforcing international commitments, and of addressing the new opportunities for criminal activity produced by globalization. As Crawford notes, "the question has changed. It is no longer whether we are going to have an international criminal tribunal but what sort of international criminal tribunal we are going to have." ${ }^{55}$ With a subject-matter model of jurisdiction, the International Criminal Court can give substance to the concept of humanity, building an international community based on both the shared human interests in preserving life, avoiding suffering, and maintaining human dignity, as well as the commitment to the rule of law.

\footnotetext{
${ }^{54}$ Richard A. Falk, Human Rights Horizons, p. 186.

55 James Crawford, "Prospects for an International Criminal Court," in John Dugard and Christine van den Wyngaert (Eds.), International Criminal Law and Procedure, p. 474.
} 


\section{Bibliography}

Amnesty International Online. "Universal Jurisdiction: The Duty of States to Enact and Enforce Legislation." www.web.amnesty.org/web/web.nsf/pages/legal_ memorandum

Ando, Nisuke, Edward McWhinney, and Rudiger Wolfrum. (Eds.) Liber Amicorum Judge Shigeru Oda. Vol. 1. Kluwer Law International. 2002.

Arend, Anthony Clark. Legal Rules and International Society. Oxford University Press Inc. 1999.

Buchanan, Allen. "From Nuremberg to Kosovo: The Morality of Illegal International Legal Reform." Ethics. Vol. 3. No. 4. July 2001.

Cunningham, Robert L. (Ed.) Liberty and the Rule of Law. Texas A\&M University Press. The Liberty Fund Inc. 1979

Dugard, John, and Christine van den Wyngaert. International Criminal Law and Procedure. Dartmouth Publishing Company Limited. 1996.

Dworkin, Ronald M. (Ed.) The Philosophy of Law. Oxford: Oxford University Press. 1977.

Dworkin, Ronald M. "Natural Law Revisited." In Joel Feinberg and Hyman Gross. Philosophy of Law. $5^{\text {th }}$ Edition. Wadsworth Publishing Company. 1995.

Dyzenhaus, David. Legality and Legitimacy: Carl Schmitt, Hans Kelsen and Hermann Heller in Weimer. Oxford: Clarendon Press. 1997.

Hart, H. L. A. “A More Recent Positivist Conception of Law.” In Joel Feinberg and Hyman Gross. Philosophy of Law. $5^{\text {th }}$ Edition. Wadsworth Publishing Company. 1995.

Hart, H. L. A. "Positivism and the Separation of Law and Morals." In Joel Feinberg and Hyman Gross. Philosophy of Law. $5^{\text {th }}$ Edition. Wadsworth Publishing Company. 1995.

Hoffman, John. Sovereignty. Minneapolis: University of Minnesota Press. 1998.

Hitchens, Christopher. Trial of Henry Kissinger. Verso Press. 2002.

Hutchinson, Allan C., and Patrick J. Monahan. (Eds.) The Rule of Law: Ideal or Ideology. Carswell. 1987.

Kissinger, Henry A. "The Pitfalls of Universal Jurisdiction." Foreign Affairs. Vol. 80. No. 4. July/August 2001. Pp. 86-96.

Krasner, Stephen D. Sovereignty: Organized Hypocrisy. Princeton, New Jersey: Princeton 
University Press. 1999.

Kriegel, Blandine. The State and the Rule of Law. Marc A. LePain and Jeffrey C. Cohen. (Trans.) Princeton, New Jersey: Princeton University Press. 1995.

Lawyers Committee on Human Rights. International Criminal Court Briefing Series. May 1998. Vol. 1. No. 1. http://www.lchr.org/icc/pap1rev4.htm

Lee, Roy S. (Ed.) The International Criminal Court: The Making of the Rome Statute. Kluwer Law International. 1999.

McKay, Fiona. "Universal Jurisdiction in Europe: Criminal Prosecutions in Europe Since 1990 for War Crimes, Crimes Against Humanity, Torture, and Genocide." http://www.redress.org/unijeur.html

Monahan, Patrick J. Constitutional Law. Irwin Law. 1997.

Nguyen, Katie. "Landmark Ruling: Belgian Court Dismisses Sharon War Crimes Suit." June 26, 2002. abcnews.go.com/sections/world/DailyNews/sharon020626_suit.html

Nizkor Project, The. http://www.nizkor.org/hweb/people/e/eichmann-adolf/transcripts/ Judgment/Judgment-002.html

Pagden, Anthony and Jeremy Lawrance. Political Writings - Francisco de Vitoria. New York: Cambridge University Press. 1991.

Raz, Joseph. Authority. Basil Blackwell Ltd. 1990.

Reisman, W. Michael. (Ed.) Jurisdiction in International Law. Brookfield, Vermont: Ashgate. 1999.

Roth, Kenneth. "The Case for Universal Jurisdiction." Foreign Affairs. Vol. 80. No. 5. September / October 2001.

Saland, Per. "International Criminal Law Principles." In Roy S. Lee. (Ed.) The International Criminal Court: The Making of the Rome Statute. Kluwer Law International. 1999.

Saul, Ben. "In the Shadow of Human Rights: Human Duties, Obligations, and Responsibilities." Columbia Human Rights Law Review. Vol. 32. No. 565. 2001.

Schabas, William A. An Introduction to the International Criminal Court. Cambridge University Press. 2001.

Schauer, Frederick. Playing By The Rules: A Philosophical Examination of Rule-Based Decision-Making in Law and in Life. Oxford: The Clarendon Press. 1991. 
Schwarzenberger, Georg. International Law as Applied by International Courts and Tribunals. Volume 2. London: Stevens \& Sons Limited. 1968.

Sewall, Sarah and Carl Kaysen. The United States and the International Criminal Court: National Security and International Law. Lanham, Md: Bowman and Littlefield Publishers. 2000.

Simons, William B. "The Jurisdictional Bases of the International Military Tribunal at Nuremberg." In George Ginsburgs and V. N. Kudriavtsev (Eds.). The Nuremberg Trial and International Law. Kluwer Academic Publishers. 1990.

United Nations Secretary-General 1946 - 1953. Historical Survey of the Question of International Criminal Justice. United Nations - General Assembly, International Law Commission. Lake Success, New York. 1949.

Wallace, Rebecca M. M. International Law. $3^{\text {rd }}$ Edition. London: Sweet and Maxwell. 1997.

Wapner, Paul and Lester Edwin J. Ruiz. (Eds.) Principled World Politics: The Challenge of Normative International Relations. Rowman \& Littlefield Publishers, Inc. 2000. 